\title{
Considerations on the European Companies and holdings
}

\author{
Roxana Maria CHIRIEAC \\ Titu Maiorescu University, Bucharest, Romania \\ roxana.chirieac@gmail.com
}

\begin{abstract}
In a political and economical climate that one might qualify as troubled, and on the background of the United Kingdom leaving the European Union, and therefore no longer offering the city of London as a light tax haven for the companies that don't undergo transactions of economical substance on its territory, one might question the survival of transnational companies across the European Union. In this context, we thought of analysing the European companies, their history and their present day formation as well as their administration. The idea that one might carry out their activity throughout the European Union, using a simpler and lighter form of company, the idea that the administration of such company is easier and one doesn't have to comply to the national legislation of each member state is indeed appealing. But what of the success of this regulation? Is the procedure indeed as simple as it was thought out to be, and if so, are the natural and moral persons using it to its full capacity? Also, on the other hand, what of the holding institution, generated by the common law system, a lot longer ago, which allows one to administer various companies in various states through a company that is located anywhere in the world. How are holdings incorporated, how are they administered and is this institution still in use in the European Union, considering the fact that one might set up a European company as a holding?
\end{abstract}

Keywords: European companies, holdings, European Union, Societas Europeas.

\section{Introduction Into the European Companies}

The European companies have long been a theme of discussion for the European Union, therefore ever since its creation there has been this idea of forming a type of company that would unite and regulate the common market.

The idea of a European transnational company started at the ending of the XIX ${ }^{\text {th }}$ century, and evolved from the need to trade between the countries of the old continent. Therefore, "the first steps towards an international company statute were for a long time related to the creation of specialized transnational companies which were needed for different projects, with a special law designed for them and not real provisions addressed to the market, creating a status possible to be accessed by the entrepreneurs" (Dumitru, 2017).

Due to the very different type of regulations scattered all across Europe, even by forming a transnational company, one could never be completely sure of its success and performance. Not mentioning the fact that most of Europe follows the continental law system tradition as pertaining to regulations and the United Kingdom follows the common law system, even in the continental system one can find various differences between regulations: (i) regarding the types of companies one can establish, (ii) regarding their functioning and administration, (iii) regarding the taxation to which one is submitted according to the type of company one is establishing.

Thus, the economic reality that settled in after the second World War, a period of reconstruction and collaboration, had to be closely followed up by regulations in accordance: "the first important trigger [in the European companies] was represented by the founding treaties enacting the European Communities, mainly due to its connection with the creation and development of the common market and the free movement of people, goods, services and capital, with all their effects" (Dumitru, 2017). 
Even so, withstanding the pressure exerted by the economic and business environment, the reality of a European type of company only materialized in the XXI century, in 2001. This being said, there was a lot of pressure from community members that wished to impose their view and legislation to the European scale. A lot of talk was generated by the proposals of the European Commission, mainly between France and Germany. Each leading country and member of the original European Economic Community wanted and felt the need to impose their system or at least influence the new regulation of the European company.

The topics of discussion were principally concentrated on the minimum amount of legal capital that a company needed to have in order to incorporate as an European company (where France and Germany stood as opposite parties as the first advocated that there shouldn't be a minimum capital required, the second considered that it should be imposed) and the right of employees be part of the board of the company and weather or not the new type of company could be constituted as a company able to issue barer shares.

The Commission however felt very differently about this topic and remained clear that its goal with the said regulation was not to try and harmonize the different legislations of different law systems or countries, but to create a new regulation that should overrule all the national regulations. Thus, given the principals of exclusive and shared competences of the European Union, they made the new regulation on the European company in such way that it would be applicable in an uniformed way, for all member states and could be prioritized to application, before all national regulations.

The European integration has always progressed in small steps and this new legal frame was a necessary step in this process. It would seem that it is still up to the Court of Justice to push European Union law forward in this area. However, the Court does not have the power to harmonize. Therefore, for now, the States must be the primary engines of this transformative process. Unless the States understand that harmonization is the lesser evil (Parleani, 2013), there shall be little hope for the European groupings (EEIG, SE, SEC, and perhaps soon the SPE).

Even when the regulation came out, some countries had difficulties in implementation; for instance Italy, whose national legislation forbid barer shares, had to find ways in order to implement the European Regulation. Today, this issue has disappeared, as with Directive no. 2015/849 of the European Parliament and of the Council of 20 May 2015 on the prevention of the use of the financial system for the purposes of money laundering or terrorist financing, amending Regulation (EU) No 648/2012 of the European Parliament and of the Council, and repealing Directive 2005/60/EC of the European Parliament and of the Council and Commission Directive 2006/70/EC and the Council Directive no. 2016/2258 of 6 December 2016 amending Directive 2011/16/EU as regards access to anti-money laundering information by tax authorities. Both legal acts aim to reduce money laundering and expose the ultimate (real) beneficiary owner of companies (but especially offshore structures), thus taxing the said person. Also, most of the European Union's states chose to implement these two directives by simply removing from their in force legislations the bearer shares.

The European companies are regulated firstly by the Council Regulation no. 2157/2001, issued on the $8^{\text {th }}$ of October 2001 on the Statute for a European company (S.E.), and the Council Directive 2001/86/CE of the $8^{\text {th }}$ of October 2001 supplementing the Statute for a European company with regard to the involvement of employees, with the subsequent amendments and additions. 
It was transposed in the Romanian legislation by the Government Emergency Ordinance no. 52/2008 that modified the Law no.31/1990 regarding companies and the Law no. 26/1990 regarding the Trade Registry.

What is very particular for this regulation is that the Council chose to name this type of company by its Latin translation, Societas Europaea, or in short S.E. It is our belief that this was made in the attempt to harmonize and limit the attempt of member states to marginalize this regulation.

Despite the best efforts submitted by the European Commission when creating the legal framework for the European companies, we may ask ourselves about the success of the said structures. Unfortunately there is no clear database that one may access in order to clearly establish the number of European companies registered to the present day. In March 2016, there were only 2525 registered European Companies, mostly incorporated in France, Germany, Czech Republic or Slovakia. Most of them are international and transnational companies, created before the regulation was conceived for European companies; they are companies such as Airbus, Allianz, LVMH Moet Hennessy Louis Vuitton, Schneider Electric or E.ON. To the present day, the same study states that there are 3286 European companies established in the European Union (ETUI (2014)). The same source clearly states that the provided statistics may be deceiving as there is no official institution that keeps track of the European companies, and the said study only registers the voluntary participation of the companies. Also, it is important to note and stress out that many of the registered European companies don't comply to the standard definition of this type of company - as the study warns us " in their overwhelming majority, SEs without employees ('empty SEs') and/or even without a specific business purpose ('shelf SEs')" (ETUI (2014)).

This actually means that most of the European companies that were created in the Union were made out to be holdings and used in accordance with this purpose.

On the other hand, common law systems have a longstanding tradition of holding companies and they developed different types of ways in order to set them up. "Traditional" holding companies in common law countries are usually set up in tax havens that allow less control and offer the possibility of legal tax avoidance. The banking and legal entities even formed legislations dedicated mostly to hosting offshore companies, such as the British Virgin Islands, Cayman Islands, Liechtenstein, Switzerland, Ireland, Hong Kong or even Delaware in the United States. Some might argue that the states listed above are no longer tax havens and they no longer fulfill their role as offshore-preferred destinations. It is true that things have changed as from the 2008 economic crisis, the United States and then the European Union started to move forward as to find ways to bring the assets back into their country of origin and ask their citizens to pay taxes on the wealth they detained. Also, with the growing threads of terrorism, regulations got even tougher for the banks and law firms who had to become more and more creative as to the ways they were administering the companies registered with them. This being said, there is no evidence that the above mentioned states are no longer fiscal paradises - due to the lack of complete and correlated data and the ever changing regulations on tax, terrorism and criminality in general, there are very few concrete and certain data pertaining to real statistics on offshore companies in the present.

For this study, we wanted to analyze and see weather the European company is a viable alternative for traditional transnational holding companies that have been operating in the world so far. Also, it would be interesting to note if the European company may be used for legal tax avoidance purposes, and if so, to what extent the administration of a European company is 
helpful in implementing a plan in order to reduce the amount of tax that a company can legally pay. For the purpose of this study, we first thought to analyze the European company structures and how it is administered. In a second step of our study, we shall analyze the holding types of companies that are usually registered in the common law systems and shall see the differences and similarities (if any) in the above mentioned types of ways to exert a business.

\section{The European Companies - Present Regulations}

PICBE $\mid 1170$

As mentioned above, the present regulation of the European companies is mentions by the Council Regulation no.2157/2001 (herein after mentioned as Council Regulation) and the Council Directive 2001/86/CE (herein after mentioned as Council Directive).

The Council Regulation fails to provide a clear definition of the European companies, but the doctrine considering the ensemble of the framework and the regulation established that the European companies can be defined as a type of limited liability company, that issues shares, having its own full concrete legal capacity, established by one of the ways provided by the Council Regulation and whose legal regime is ruled by the said regulation as well as the law system of the member state where the company is incorporated with its registered office. (Sitaru, 2017).

The Council Regulation clearly defines the traits of a European company as follows: (i) the company shall have its capital divided into shares - which are by essence negotiable titles and the liability of each of its shareholders shall be limited to the amount he subscribed by his shares (article 1, paragraph 2); (ii) the European company shall have legal personality (article 1, paragraph 3) - this means that it will be able to perform any type of activity according to all established law systems in the European Union; (iii) for the establishment of European company, one must follow the provisions given by the Council Regulation (article 2), meaning that a European company can't be incorporated as such only using the provisions given by the national legislation of a member state and finally (iv) the status of a European company shall primary be ruled by the Council Regulation (article 9), and only if the mentioned provisions don't cover a certain topic, then the national legislation of the member state where the European company has its registered office shall become applicable. If the mentioned member state doesn't have specific provisions for the European company, then the national provisions regarding the anonymous company (joint stock company) shall become applicable.

The companies created with respect to the Council Regulation "don't have $<<$ a European nationality $>>$, but they posses the legal personality of the registration (incorporation) state, who must provide diplomatic protection in similar conditions as those offered to national companies" (Sitaru, 2017).

A European company may be set up in only four ways, listed in article 2 of the Council Regulation: first, by merger of two or more public limited companies, second by forming a holding company by two or more existing companies, third when two or more companies decide to form a common subsidiary as an European company and fourth by transforming a public limited liability company into an European company. All of the above mentioned ways of forming a European company are provided with conditions.

Doctrine has divided these four ways of formation into two categories - primary and secondary; thus "primary creation is concerned with the cases were there is no involvement of a pre-existing SE. In this case, a SE can be created by means of mergers of public limited companies. Also, a holding $S E$ can be initiated between public limited companies; whilst another opportunity regards the creation of a subsidiary SE, with companies in accordance with the article 
48 TFUE; or the conversion into an SE undergone by a public limited company. Referring to the secondary formation, the approaches are similar, the differentiating factor being that one company is a pre-existing SE" (Dumitru, Stoican, 2019).

In order to set up an European company by means of a merger (articles 17 to 31 of the Council Regulation), one can merge two ore more companies, but only (i) if at least two of them have their registered offices in two different member states and (ii) if all companies submitted to the merger are public companies limited by shares (joint stock companies). There are two possible ways to merge: merger by fusion, in which case the new company shall become a European company and merger by acquisition, in which case the company that acquires the other company shall become a European company. In all cases, a draft for the merger must be drawn and the administration body of the companies merging must take the necessary steps to insure the publicity of the merger in all member states where the companies have registered offices. In all evidence, the general assemblies of the merging companies must approve of the merger. Then the merger plan shall be submitted to the competent authority of each member state where the companies have their registered offices (it may be the court, the public notary or any other authority mentioned by the national law of the member state). They will issue a certificate which will attest the successful completion of the pre-merger acts and necessary formalities. Then a similar certificate must be issued by the member state in which the new European company shall establish its registered office. Only then the company can be incorporated and a new publicity issued at the European Union's level. What is quite interesting is that once it has been incorporated, the European company can't be declared null and void if the above procedure of certification is not respected, but it can constitute grounds for its winding-up.

In order to form a European company by forming a holding (articles 32-34 of the Council Regulation), two or more public companies limited by shares (joint stock companies) and/or limited liability companies must have their real registered offices in the European Union (meaning they must undergo activities of economic substance in Europe) and must fulfill alternatively one of the following conditions: (i) is governed by the law of a different Member State, or (ii) has for at least two years had a subsidiary company governed by the law of another Member State or a branch situated in another Member State. To this end, the administration body of the companies must draft a project for the formation of a holding, and such project will be publicly submitted in accordance to the laws of the member states in which all companies have registered offices. The project must be approved by all general assemblies, and the incorporation of the holding company can only be done if the minimum amount of shares/social parts is distributed. If all the conditions are met, the holding can be incorporated with respect to the publicity provided by the national law of the state where it shall be registered. The imperative condition for the incorporation of a holding company is that all companies contribute to the formation of the capital of the holding in such a manner that the holding is conferred more than $50 \%$ of the permanent voting rights to the establishing companies. It is important to note that only limited liability companies may for an SE holding; doctrine has pointed out and analyzed the working papers of the European legislator and determined that "it is not practical to permit forms of business enterprises other than public and private corporations to form an SE through the use of holding company. A relaxation of the current restrictions, for example, would require that partners contribute their partnership interests in exchange for shares in a newly created SE corporation. The corporation would then own the partnership interests in the two founding partnerships. In most member states, the laws governing partnerships are substantially different 
from the laws that govern corporations." (Blackburn, 1993), thus creating a lot of confusion as to the setting up of the SE.

For the formation of a common subsidiary constituted as an European company (articles 35 and 36 of the Council Regulation), any legal body public or private who has its registered capital in a member state can form such a company, provided that they respect the provisions provided by the national law where the subsidiary is going to be incorporated and that at least two of the participating legal bodies comply with one of the following: (i) are governed by laws of different member states or (ii) have had a subsidiary company governed by the law of another member state, or a branch in a different member state, for at least two years. This particular way of setting up a European company has no particularities and shall be submitted entierly to the same procedure regulated by the national legislation of the member state where it is going to be registered.

Last, a European company can be registered by converting a pre-existent public limited liability company into a European company (article 37 of the Council Regulation). There is a necessary condition that the company subjected to the conversion must have a subsidiary in another member state, other then the one where it has its registered offices, for at least two years before the conversion. This process follows almost the same steps as the first two, but doesn't imply the dissolution of the company subjected to the conversion. It also doesn't lead to the creation of a new legal person. It simply states that one company shall become a European company (thus the necessity of having a subsidiary in another member state) by transferring its registered offices to another member state.

Given the economic context for now, European groupings still have to rely on market forces and on a few scandals, to make the States understand that harmonization is the only way to coexist and be efficient together on the European market (Parleani, 2013).

All types of European companies will be incorporated in a member state and shall have statutes, meaning company contracts and statutes (which together according to our national legislation can be called constitutive acts). All European companies shall be followed by the initials "S.E.", that can't be used by any other type of company in any member state and all of them must have a registered capital of at least 120.000 euros. If the member state where the company is registered has a larger amount of registered capital required for a certain type of activity, the national legislation shall prevail before the European one. All European companies can transfer their registered offices to another member state, without this procedure being considered as liquidation or a new setting up of companies. They can also set up subsidiaries in other member states without complying with the national regulations as regards to the minimum number of associates or shareholders provided by a certain type of company.

The European companies can be administered in one-tier or two-tier system. There shall always be a general meeting of shareholders that will supervise the activity of the company, and shall meet at least once every year. The one-tier system of administration (articles 43-45 of the Council Regulation) shall consist of an administrative organ, formed by at least three members, where one of the members shall be a representative of the employees. The two-tier system (articles 39-42 of the Council Regulation) shall be administered by a supervisory organ, appointed by the general shareholders meeting, that will in its turn appoint the management organ. The supervisory organ has no power to manage the company, but has merely the role to supervise the management organ, which in its turn is obligated to report to the first at least once every three months. 
However, member states may derogate from the above mentioned rules, in accord with provisions for public limited liability companies, provided in their national legislation (example: for the naming of the management organ, a member state might choose for it to be appointed by the general shareholders meeting, or it may change the minimum or maximum number requested for the supervisory organ or the management organ).

In regards to the winding up, liquidation, insolvency and cessation of payments of the SE, in other words, the termination of a company's life, we point out the provisions of Title V, articles 63-66 of the Council Regulation. They assert that national provisions regarding these matters applicable to public limited liability companies of the Members State where the SE has its registered office shall also be applicable to the $\mathrm{SE}$, in all aspects (including the decision took by the general meeting). The Council Regulation states in art. 30 that a SE company formed by merger can't be declared null and void if the SE has been registered, but the lack of scrutiny of the legality of the merger might constitute grounds for winding up the company. However, we rally to doctrine's opinion that in regards to winding up, this Council Regulation must be corroborated with the provisions Directive (EU) 2017/1132 relating to certain aspects of company law which "in order to safeguard the third parties interests in respect of the second paragraph of art. 58 from the EEC Treaty, throughout all Member States, the nullity of commercial companies" might only be pronounced by the grounds set out by the abovementioned act (Lefter, Dumitru, 2009).

The Romanian companies law states that a company must be liquidated if the established duration of functioning mentioned in the constitutive act has passed, reason that is not mentioned by either EU regulations. Doctrine has determined that "in principle, after the expiration of the term for which the company was created, the associates can not extend its duration, and a contrary decision leads to the creation of a new commercial company" (Lefter, Dumitru, 2011), even if Romanian courts have admitted the prorogation of the companies life. This implicates that any act made by a company, after the expiration of the duration mentioned in its constitutive act is null and void, as in theory the company doesn't have a legal personality anymore. This ground of winding up has not yet been determined by any EU provisions and may have practical implications where an SE might be set up for a respective period of time.

With reference to the participation of the employees to the management of the company, it was discussed and set up by a different normative act, the Council Directive. As it is a directive and each member state implemented it in accordance to its national legislation, we shall only present, in short, the guidelines for the implementation; as such the Council Directive focuses mainly on the negotiation phase that should take place at the founding of the company and should establish the involvement and the ways of engaging by which the employees may participate to the company's life: "a specialized body, whose members are chosen proportionally to the employees of each company/subsidiary or establishment, is formed such that negotiations can be initiated. Decisions are taken with an absolute majority of the members, but there are also cases when qualified majority is used (for example, in the case of a cutback of participations rights). The Directive also includes the Standard Rules which have to be put into action by each Member State in case the negotiations reach no conclusion." (Dumitru, Stoican 2019). The Council Directive was transposed into the Romanian legislation by the Government Decision no. $187 / 2007$ regarding the information, consulting procedures and other ways of involving the employees in the activity of the European company.

What is interesting to note is that the Romanian legislation never implemented any type of regulation in order to sort out a possible conflict of interest between the persons chosen to 
represent the interests of employees during the negotiations. The transposition of the Directive only sets out that the employees shall be represented by members of the syndicate, if such syndicate exists, and if not they shall be chosen form the employees. A conflict of interest may be defined as "a set of circumstances where there is a risk that a professional judgment or actions relating to a principal interest will be unduly influenced by a secondary interest. As such, the main interest relates to the main activity objectives, as for example the business partners, consumer protection etc., while the secondary interest includes personal benefit that is not necessary limited to financial gain, but can also consist in other reasons (such as family and friends favors). These secondary interest are not automatically treated as a negative element of their own, but become unacceptable if they affect the main interest" (Stoican, 2019). Therefore, we can't help but wonder, weather the representative of the employees can be coped by the main shareholders of the new SE, and as a consequence the main goal of the Directive can be eluded.

\section{Holding Companies - A Viable Alternative?}

Holdings have a long-standing tradition in the common law regulations, meaning that they have been used for all kinds of transactions from administrating wealth of private individuals to performing international business transactions. A holding company is a commercial company that holds capital participations in other companies or groups of firms, exerts control over them and doesn't itself perform economic or commercial activities (Afrăsinei, 2016).

A holding company can exert its control either in a direct or indirect manner (for instance it may hold participation directly in another company, or by one or more intermediaries). This usually varies according to the percentage in which the company is held - if the participation to the company is more than $50 \%$, the holding will be named a mother company.

A holding can be set up as any kind of structure as private or public limited liability companies or as trusts or fiducias (anshalts in Liechtenstein), and may be run by a board formed by lawyers and/or bankers. There are no specific provisions regarding the constitution and the formation of the board as it varies depending on the type of establishment and on the legislation of the country where it is incorporated. In our opinion, this may count as an important advantage for the ultimate beneficiary owners who may choose to set up these kinds of structures, as they may run them as they see fit. Subsequently, there is little to non-involvement of the board, that may follow the indications of the beneficiary owners, and there is even less involvement from the employees of the companies who have no positions in the administration of the company.

Though it may seem appealing to set up a holding within the European Union, as many articles of the founding treaties impose the right of establishment of companies, there are also a lot of in place regulations that limit the possibility of a holding to act as such, meaning to only detain capital in other companies: several times groups of experts advocated that the Commission set up regulations in this optic. One of such recommendations was to require "national authorities, responsible for the admission to trading on regulated markets, not to admit holding companies whose sole or main assets are their shareholdings in another listed company, unless the economic value of such admission is clearly demonstrated." (Andenas, 2008) Thus, we may say that a holding created for the sole purpose of holding assets will be dealt with as a type of shell company, especially in the light of recent regulations that impose member states to declare the ultimate beneficiary owners as natural persons for all companies that are registered in that member state.

Concerning the grounds for winding up a SE, one might add that a member state can oblige the company to have its head office in the same place as its registered office, under the 
sanction of liquidation (articles 64 corroborated with article 7 of the Council Regulation). Thus, even when setting up a holding by means of an SE, the company might still be pressured into being ran by and under certain provisions of a national law, which might not always be favorable to the holding. Such provisions might impose a variety of restraints in administrating the company, such as higher number of votes or a larger quorum than a non-EU legislation.

As mentioned before, a holding company doesn't undergo any economic or commercial activity of substance (meaning they only deal with paperwork and don't actually perform any type of activity on their own). This being said, they may relocate as it is most convenient for taxation purposes. If a holding is registered in the EU, one might find it difficult to relocate to another state, even another member state and still maintain the status of a company incorporated under the laws of the first member state. This was the case for the UK and still is the case for Germany. In the Daily Mail case, the company wanted to transfer its central management to the Netherlands in order to avoid higher taxation but also maintain its legal personality and UK company status, but was conditioned to do so by the Treasury consent. It then invoked provisions of articles 43 and 48 of the Treaty establishing the European Community, but "the Court held that as far as primary establishment is concerned, said articles do not confer on a company incorporated under the law of a member state, the right to transfer its central management and control and its central administration to another member state while retaining the status of a company incorporated under UK law. Differences in national laws regarding the connecting factors cannot be solved on the basis of the Treaty Rules on freedom of establishment. [...] in Daily Mail, the issue at stake was weather the jurisdiction of formation allows a company to transfer its actual centre of administration to another member state whilst retaining its legal personality in its state of incorporation" (Wymeersch, 2003). This being said, transferring a holding company from one state to another, even if it doesn't suppose any logistic charges, might cause the company to lose its legal personality, if it is incorporated in a EU member state.

On the other hand, when setting up a holding in a tax haven it is important to research not only the taxation available in the said state or territory, but also the existence of traties to avoid double taxation. Also, one should check upon the way the double taxation is set: most European countries tend to establish a progressive taxation, meaning that they tax it the difference between their imposition rate subtracted with the taxes they already paid in their country of incorporation.

If a company is held in a large procentage or entirely by a holding, the latter will usually administer its values portfolio and will usually organize its financing, insurance, and commerce with other intra group companies. Also, it will hold any types of valuables, corporal or intangible for the intra-group companies, such as author's rights, patents, trademarks, inventions, stocks, bonds and other assets. A holding may grant refundable or non-refundable loans to the companies that it controls. In regards to the retrieval of founds, the possibilities are endless and rest with the imagination of accountants and lawyers. For instance, a holding may receive royalties from patents or inventions, dividends, reimbursaments from loans, it may rent or sell assets within leasing contracts, or simply conclude rent or sale agreements with the companies it controls. They will appear as expenses in the companies accounting and the holding will be taxed less in its country of incorporation.

This means that one company will administer the whole economic situation of the group and will deal with taxation matters, trying to avoid in a legal manner, the taxes applied to the companies within the group. It also helps when managing more companies that have different objects of activity and that will sometimes need to trade with eachother. 
Some legislations have imposed measures in order to facilitate and encourage the formation of holding companies: for instance, in some states in America, holdings that detain participations in other companies for more than $80 \%$, will not be taxed on the dividends they get out from the said companies. Also, Switzerland, allows that holdings that hold more than $20 \%$ in other companies shall benefit from a reduction of taxes at a cantonal level, the taxes being reduced proportionally with the ration between the dividends that come from the participation quota and the gross revenue of the holding. Cantons can even stipulate exemptions of taxes at their level.

Most of the tax havens that allow a tax exemption are not located in the European Union, and as such the above-mentioned operations can't be performed in Europe, or they may be performed in a lesser percentage than in the United States or other territories.

\section{Conclusions}

According to the European Commission, in order to support business growth and competitiveness, the framework for cross-border operations must yet be improved. Therefore, consideration should be given to initiatives on the following issues: transfer of the registered office; cross-border mergers and divisions; SMEs; the European Company and the European Cooperative Society; and groups of companies. In addition to that, European legislation on the transfer of registered offices is unquestionably a "market demand". Benefits can be expected, in the light of the American experience (Commission working paper).

Holdings have a very light system of administration and they can be run by lawyers and bakers following the strict directives of the ultimate beneficiary owners. They also have very permissive ways of incorporation and are helpful when one must administer more companies that belong to the same group.

This being said, the holding system regulated in the common law has had more time to evolve and has been accessible to all types of beneficiary owners, being natural or moral persons. Also, they are no longer well regarded as they have a tendency to be located in tax havens, and are usually suspected of tax evasion and not tax avoidance. Also, as the legislation in tax havens is very protective as to the identity of the ultimate beneficiary owners, one can rarely establish the full legality of the activities that are performed though the holdings.

\section{Reference}

Afrăsinei M.B., (2016). Contabilitatea și fiscalitatea societăților offshore. Bucharest, Editura C.H.Beck;

Andenas M., (2008). EU company law and the company laws of Europe, International and comparative Corporate Law Journal, volume 6, issue 2, 31;

Blackburn T.L, (1993). The Societas Europea: the Evolving European Corporation Statute, Fordham Law Review, volume 61, 718;

Commission working paper, Impact assessment on the directive on cross-border transfer of registered office, p. 15;

Dumitru O.I., (2017) The European Company, Perspectives after Brexit, Tribuna Juridică, vol. 7 , nr. 2, 134-146;

Dumitru O.I., Stoican A., (2019). Business Law. Lecture notes. Bucharest, Editura ASE;

ETUI (2014), European Company (SE) Database, http://ecdb.worker-participation.eu/, accessed on the $14^{\text {th }}$ of February 2020 ;

Lefter C., Dumitru O.I., (2009) Theoretical and Practical Aspects Regarding the Nullity of Commercial Company, Revista de Economie teoretică şi aplicată, nr. 11, 35; 
Lefter C., Dumitru O.I., (2011). Dissolution of the Commercial Companies due to the Passing of Time Established as a Duration of the Company - Theoretical and Practical Aspects, Revista de Economie teoretică și aplicată, nr. 11 (564), 62;

Parleani G., (2013). Le transfert du siège, Revue des societies 2013, 408;

Sitaru, D.A., (2017). Dreptul comerțului internațional: tratat, ediția a 2-a. București, Editura Universul Juridic;

Stoican, A., (2019). The possible conflict of interests existing during the exercise of the mandate

PICBE | 1177 of administrator or for the position of shareholder of a company by shares regulated according to law no. 31/1990, Proceedings of the International Conference on Business Excellence, Volume 13, issue 1, ISSN 255-9652, 1772;

Wymeersch E., (2003). The Transfer of the Company's Seat in European Company Law, Law Working Paper N $N^{\circ}$ 08/2003 of European Corporate Governance Institute, 17-18. 